\title{
Legitimizing Linguistic Diversity: The Promise of Plurilingualism in Canadian Schools
}

\author{
KAREN A. KRASNY \\ York University \\ SONYA SACHAR \\ York University
}

\begin{abstract}
Policies and practice related to the production and treatment of human difference and diversity figure prominently in educational discourse related to language and identity (Piccardo, 2013; Schecter \& Cummins, 2003; Wenger, 1999). In this article, we undertake a historical review of Canadian language and multicultural policy and how it has shaped educational practice in Canadian schools. In response, we advance a critical understanding of plurilingualism as it more accurately reflects changing communities and conditions of diversity within the global context. Focusing on students as social actors and their ability to use languages for intercultural interactions, our review yields important pedagogical implications for leveraging the dynamism and interconnectedness of language competencies to reimagine Canadian classrooms.
\end{abstract}

Keywords

plurilingualism, Canadian language policy, linguistic diversity, language education, multiculturalism

\section{Introduction}

Policies and practice related to the production and treatment of human difference and diversity figure prominently in educational discourse related to language and identity (Piccardo, 2013; Schecter \& Cummins, 2003; Wenger, 1999). In this article, we undertake a historical review of multilingualism policy and practice in Canadian schools to advance a critical understanding of plurilingualism as it more accurately reflects changing communities and conditions of diversity within the global context. Our review aims to reaffirm the need to analyze and monitor the implementation of national language policy against rapidly changing linguistic demographics and Canada's participation in the global community. Our research yields insights into how language policy has shaped educational practice in Canada and where multilingualism falls short of fulfilling the promise of opportunities for personal identity (Multilingualism for Action, 1977). Focusing on students as social actors and their ability to use languages for intercultural interactions, we examine what plurilingualism might imply for leveraging the dynamism and interconnectedness of language competencies to reimagine multilingual classrooms.

Statement of the problem

At the time of writing, 18,643 Syrian refugees had just arrived in Canada and it is 
estimated that over half of these are children under the age of 14 (Levitz, 2016). Among Canadian cities, the Greater Toronto Area (GTA) has welcomed the largest number with 1,584 Government-Assisted Syrian Refugees (Immigration \& Citizenship, Government of Canada, 2016). Newly arrived, families are eager for their children to attend school and the Toronto Public and Catholic School Boards have responded with pop-up classrooms for those children whose families may still be residing in hotels. Considerable emphasis is placed on integrating these young survivors into their new homeland (Toronto Star, Feb. 10) through English language learning. A number of the schools have accessed Arabicspeaking interpreters and supply teachers to work side-by-side to run 2-hour morning classrooms. Liaising with the Syrian community through Arabic-speaking interpreters and in some cases, teachers and administrators helps put anxious parents' minds at ease about dropping off their children at school and leaving them in the care of others. At the same time, the immediacy of such a large intake underscores the need and responsibility to understand how all children can successfully employ their existing language skills and knowledge as a resource to learn in mainstream English- and French-speaking Canadian classrooms. Several years earlier, Chumak-Horbatsch (2012) reported that in the GTA approximately $50 \%$ of children use a language other than English within their homes. The Toronto District School Board (TDSB, 2014), the largest school board in Canada and one of the largest in North America, states that more than 75 different languages are spoken in homes across the board. The reality of linguistically diverse student populations across schools in Toronto and elsewhere demands our continued scholarly attention to how students' language repertoires contribute to identity, literacy and academic achievement, school engagement, and intercultural interactions with the aim of informing educational policy and practice related to fostering respect and support for cultural and linguistic diversity in schools.

Blommaert and Rampton (2011) contend, "over the past two decades, globalization has altered the face of social, cultural, and linguistic diversity in societies all over the world" (p. 1). Vertovec $(2007,2010)$ conceptualizes the global community in the context of superdiversity, where each individual is diverse in their linguistic, national, and cultural perspective. Superdiversity challenges essential ideas "(a) about languages, (b) about language groups and speakers, (c) about communication" (Blommaert \& Rampton, 2011, p. 3) and ultimately, about how we conceptualize language. Garcia (2009) uses the term plurilingualism to explain that language practices today require a different understanding with regard to the multiple languages that individuals engage in as they "cross borders either physically or virtually" (p. 54). Such migratory influences contribute to an increase in the number of students in North America whose language repertoire and practices draw from a myriad of cultural and linguistic experiences.

According to Schecter and Cummins (2003) "when increasing numbers of school populations in North American metropolitan centers come from non-English-speaking home backgrounds, the implications of this reality for policy and pedagogy are as unclear as they were in 1988." For this reason, many schools are "ill equipped to provide educational services" (pp. 2-3) in regard to these demographic trends. Teacher education preparation programs have, in large part, failed to reflect the changing demographics of twenty-first century North American classrooms. For the past thirty years, teacher education programs have "inadvertently reflected the image of the generic student in the school system as white, monolingual, and monocultural" (Schecter \& Cummins, 2003, p. 
3).

During the eighties, Ruiz (1984) recognized that linguistic and cultural diversity defined the majority of students within many school systems across North America. He argued that language as a problem and language as a right often competed for predominance in international literature on language planning efforts in any context and this tension was the source of considerable hostility and divisiveness. Ruiz strongly suggested language as a resource as the more viable orientation toward linguistic diversity. Garcia (2009) explains that many educators continue to assume that "legitimate linguistic practices are only those enacted by monolinguals" (p. 115). Viewing language learning through a monoglossic lens promotes the idea of students with home languages other than English as "second language learners or second language speakers in school" (p. 59). In the twenty-first century, however, where student demographics are highly multilingual, the notion of second language learner is questionable. Garcia (2009) insists that any language orientation framework needs to move beyond the notion of second language learners in our conceptualization of schooling and focus instead on the ways educators can approach multilingual education. Few school policies have demonstrated a consideration of language diversity that assumes language as a right and language as a resource rather than language as a problem or more recently, language as a privilege (Ruiz, 1984; Garcia, 2009). In Canada, The Official Languages Act of 1969 granting official language status to French and English has largely contributed to our conceptualization of language rights. We recognize that any policy changes in support of linguistic diversity require a concomitant investment in developing educators' understanding of how national language policies have shaped ideas about both language as a right and consequently, how language as a resource has been enacted in classrooms across Canada. A critical examination of the policies can shed considerable light on current practice and offer insights into how we might revise our historical understandings to better leverage students' home languages and literacies to strategically address issues of student identity, achievement and engagement.

In this article, we examine the historical policies in Canada that have both helped and hindered the move away from schooling and language education as a monolingual enterprise. Drawing on Bourdieu, we further argue in favour of an orientation that accounts not only for language as a right and language as a resource, but language as cultural capital that includes "all goods material and symbolic without distinction that present themselves as rare and worthy of being sought after in a particular social formation" (Bourdieu, cited in Harder, 1990, p. 13). More specifically, reaching beyond the bounds of provincial and national policy and the persistent binary projected in the literature on multilingual classrooms (i.e., home language maintenance/target language), we take up the Council of Europe's (2007) definition of plurilingualism to demonstrate that the communicative ability in a number of languages in accordance with an individual's needs can be an important form of embodied capital that is inherited and acquired, though not in the genetic sense but rather through a process of socialization whereby time, culture, and traditions are bestowed intergenerationally within and across families (Krasny, 2009). Through a critical comparison of a succession of federal policies and frameworks that focused largely on the role of language in nation-building, we encourage educators to think about how students can enact their knowledge of multiple languages in linguistically diverse classrooms that more fully recognizes students as social actors in a dynamic global linguistic landscape. 
Why is it Important to Analyze Language Policy?

Ozga (2000) argues that there are different ways of defining policy and "that there is no fixed, single definition of policy" (p. 2). Instead, she interprets "policy as a process rather than a product, involving negotiation, contestation or struggle between different groups of people who may lie outside the formal machinery of official policy making" (p. 2). For example, in education, policies serve to control institutionalized space and the practices that educators use within the classroom setting. In this way, it is important to analyze such policies to provide a critical assessment of the educational system with the aim of making recommendations and fostering improvements at various levels of jurisdiction (e.g., school, board level, provincial ministry and federal government). Analyses aimed at understanding language policies and their outcomes are particularly important in education because they can reveal how such policies are used as mechanisms of power and manipulation. Shohamy (2006) argues, "language policy (LP) is the primary mechanism for organizing, managing and manipulating language behavior as it consists of decisions made about languages and their uses in society" (p. 45). Shohamy (2006) elaborates upon the difference between language policies versus de facto language policies (i.e. Language practices)" (p.xv). De jure policies are those that are considered to be overt, formulized, and manifested (Shohamy, 2006). On the other hand, de facto language policies are covert policies arising from various hidden agendas reflecting language ideology and practice that rely on "overt and covert mechanisms, used mostly (but not exclusively) by those in authority" (p. xv). According to Shohamy (2006), language policies cannot be thought of as simply documents, but rather should be interpreted as devices of power and manipulation that determine the status and role of languages in society.

\section{Canadian Language Policies in Recent History}

Our historical review examines the aims and educational implications of four major national language policies and frameworks implemented over the past fifty years: The Report of the Royal Commission on Bilingualism and Biculturalism (1963-1970), the Official Languages Act (1969), the Multiculturalism within a Bilingual Framework (1971) and the Multiculturalism Act (1988). We demonstrate how school policy and practice related to language rights in Canadian classrooms bear direct relation to the principles enshrined in national policies. Our research is intended to provide insights into current policy (including curricular mandates and outcomes) and the extent to which it supports or counteracts the longstanding "image of a generic student in the school system as white, monolingual, and monocultural" (Schecter \& Cummins, 2003, p. 3).

\section{Royal Commission on Bilingualism and Biculturalism (1963-1970)}

The 1960s signified a growing recognition of diversity on the part of the Canadian federal government. It was during this period that a change in federal immigration policies brought increased numbers of non-European immigrants, contributing to greater linguistic and cultural diversity within Canada and Ontario (Anderson \& Jaafar, 2006). In response to these changing demographics, the federal government implemented various policies aimed at minimizing rising tensions amongst various groups (e.g. Royal Commission on Bilingualism and Biculturalism) (Dagenais, 2013).

As Canada continued to reflect growing ethnic diversity, there was great concern regarding the status and maintenance of French and English. In 1963, Prime Minister Lester 
Pearson established the Royal Commission on Bilingualism and Biculturalism (B\&B Commission) that continues to be regarded as the "most influential commission in Canada history" (Laing, 2013). Haque (2012) deftly illustrates the relations among language, race, and nation-building during this period to frame the Commission's inquiry, which was said to be a "theatre of power" (p. 73). She explains that the Commission aimed at fostering a greater sense of belonging among Canadians by tackling three major areas of interest: radical changes to immigration policy, the federal government's ongoing attempts to abolish the Indian Act, and the rise of Quebec linguistic nationalism and independence movements. The commission's aims were directed at 1) the degree of bilingualism in the federal government, 2) the responsibility of both public and private organizations encouraging greater cultural relations; and 3) greater opportunities for Canadians to become bilingual in French and English (Laing, 2013). The commission was also to

...inquire and report upon the existing state of bilingualism and biculturalism in Canada and to recommend what steps should be taken to develop the Canadian Confederation on the basis of an equal partnership between the two founding races, taking into account the contribution made by the other ethnic groups to the cultural enrichment of Canada and the measures that should be taken to safeguard that contribution (RCBB, 1968, Appendix 1, p. 309, emphasis added).

Among its general recommendations, the B\&B Commission established English and French as de facto official languages throughout Canada and recommended special schools for French and English official minorities and the nationwide teaching of their languages. While the commission also recommended the development of a national policy to reflect Canada's ethnic diversity, the B\&B Commission's reference to bilingualism, biculturalism and two founding races brought widespread criticism from Indigenous groups and other ethnic groups. Such groups were later regarded as a third force in forging Canada's multicultural policy. Among the strongest voices in this third element, was the UkrainianCanadian diaspora (Lalonde, 2006). In response, the federal government established the Official Languages Act in 1969 with the Multiculturalism within a Bilingual Framework soon to follow in 1971.

\section{Official Languages Act (1969)}

The Official Languages Act of 1969 declared Canada a bilingual country with French and English as its official languages. Bilingualism was to be reflected in federal and provincial levels of government in Canada and their administrative bodies. Education was seen as a means of ensuring one's ability to fully participate in Canadian society. Accordingly, parents had the right to educate their children in either French or English and mandatory curriculum in the official language other than the school's regular language of instruction took hold. The act validated terms such as mother-tongue and official languages that ultimately shaped the educational imaginary with regards to languages in schools. Furthermore, the act set time limits for implementation of bilingualism in provincial and federal government offices and nominations and promotions of relevant personnel by the Public Service Commission that effectively worked to incentivize French instruction in English schools across Canada for years to come. Mackey (2010) explains that the 
implementation of Official Languages Act created a number of tensions. Creating bilingual districts and making the public service bilingual was not easily achievable in language minority areas. Additionally, Dagenais (2013) explains that such a declaration created divisiveness among an ethnically and linguistically diverse population and seen to discourage individual's linguistic practices. In 1971, in attempt to calm a number of these rising tensions, Canada embarked upon the national project known as Multiculturalism within a Bilingual Framework.

\section{Multiculturalism within a Bilingual Framework (1971)}

Pierre Elliot Trudeau's liberal government launched the national project Multiculturalism within a Bilingual Framework as a direct response to B\&B Commission of the 1960s. The framework advocated "there are two official languages, there is no official culture, nor does any ethnic group take precedence over any other. No citizen or group of citizens is other than Canadian..." (Canada, House of Commons Debates, 1971a, 8545). By making such claims, the goal of this framework was to investigate multiculturalism, but Haque (2012) claims it was also a way to integrate citizens into an already existing "radicalized hierarchy of belonging and citizenship rights" (p. 6). While the project's intentions were to continue and maintain bilingualism and to give recognition to multiculturalism in order to alleviate inequality, there continued to be an emphasis on a Canadian identity that all citizens were to uphold. Haque (2012) explains that this rationale, which paved way for multiculturalism; in fact, "homogeniz[ed] all groups as Canadian" (p. 223). Additionally, the continued importance of Canada's official languages that were implemented into other constitutions and policies in later years (e.g. Canadian Charter of Rights and Freedoms and Multiculturalism Act), exclude languages other than French and English by categorizing them as non-official.

Through the analysis of archival material related to the B\&B Commission and in particular, those related to contributions made by Ukrainian linguist Jaroslav Rudnyckyj, Haque (2012) establishes how language became the essential criteria for determining the founding "races" thereby casting other groups on the ethnic periphery for whom cultural maintenance was relegated to a private sphere denied institutional support. Competing approaches to languages and multiculturalism and lack of consensus on terms of reference effectively led to a hierarchicalization of languages and cultures, which Haque characterizes as "racial ordering."

\section{Linguistic and Cultural Subjugation}

We argue that a plurilingual approach to language education can provide a partial corrective for the homogenizing effects of long-standing multicultural policy that, in our view, continues to tacitly perpetuate cultural categorization and a linguistic hierarchy that has served to subjugate languages other than French and English. While much of the argument for a plurilingual approach to language education relies on data related to global migration, we are compelled to point out the devastating effects language policies and educational practices have had on Canada's ancestral languages. Our view is perhaps best supported by harrowing accounts of residential school survivors who provide us with first hand accounts of Canada's efforts to forcibly assimilate 150,000 Aboriginal/First Nations children over the course of more than a century by removing them from their families and communities and depriving them of their ancestral languages. 
The Official Languages and Bilingualism Institute at the University of Ottawa reports that in 1996, 67.8\% of persons claiming Aboriginal ancestry spoke English as their mother tongue, while 5.8\% spoke French. According to the report of the Royal Commission on Aboriginal Peoples (RCAP, 1996), "[w]hile more than a million people claimed Aboriginal ancestry in the 1991 census, only 190,165 said an Aboriginal language was their mother tongue, and 138,105 reported using their Aboriginal mother tongue in the home." Canada's ancestral languages are some of the oldest in the world, dating back thousands of years, yet a survey conducted by the Assembly of First Nations (AFN) in 1990 and 1991 showed that of the 53 First Nations languages spoken on Canadian reservations, 50 were becoming extinct. Presently, between the estimated 50 and 70 aboriginal languages still spoken across Canada, only Cree, Inuktitut, and Ojibway are spoken by a large enough population to be safe from extinction. While plurilingualism may have emerged as a democratic ideal defined by the Council of Europe (2007) and gained traction in Canada in response to globalization (Coste, Moore, \& Zarate, 2009), it is our expressed hope that readers, too, will contemplate plurilingualism's potential to redress Canada's systematic denial of Indigenous peoples' right to perform individual and cultural identities through language.

\section{Plurilingualism}

The term plurilingualism conceptualizes language use in the twenty-first century to open new perspectives in language education (Coste, Moore, \& Zarate, 2009). Following the Council of Europe's (2007) definition of plurilingualism, Coste et al. (2009) elaborate beyond the European context to encompass the wider global community to reflect linguistically changing demographics. Accordingly, plurilingualism

...refers to the ability to use languages for the purposes of communication and to take part in intercultural interaction, where a person, viewed as a social actor has proficiency, of varying degrees, in several languages and experience of several cultures. This is not seen as the superposition or juxtaposition of distinct competences, but rather as the existence of a complex or even composite competence on which the social actor may draw (p. 11).

This definition recognizes and accepts one's linguistic competence in all languages. Doing so works to reduce any barriers or hierarchy between the languages in one's linguistic repertoire. Various authors (Piccardo, 2013; Canagarajah \& Liynage, 2012) have distinguished between multilingualism and plurilingualism, to advance a further understanding of the pedagogical implications for adopting a plurilingual orientation to language education. Canagarajah and Liynage (2012) argue, "Plurilingualism allows for the interaction and mutual influence of... languages in a more dynamic way" (p. 50). What this means is that whereby multilingualism tends to separate one's languages, both societal and individual, and places greater importance on having command in each of the languages that a person speaks, plurilingualism focuses on opportunities for exploiting the interconnectedness and dynamism of all languages (Piccardo, 2013). A plurilingual approach to language education aims at fostering an awareness of how languages are at work in relation to our society and of the importance between language and culture(s) 
(Piccardo, Berthoud, Cignatta, Mentz, \& Pamula, 2011). Moving beyond multilingualism, plurilingualism recognizes that individuals can be equally competent in more than one language across a variety of contexts (European Commission, 2007). We contend that most individuals possess and demonstrate at the very least, limited access to linguistic competence in two or more languages even if it amounts to an ability to express greeting or thanks or recognize, comprehend or pronounce names of international foods on menus. For example, prior to mandatory language classes in public schools and the introduction of Core French or Immersion, monolingual Anglophone children growing up in middle class homes across Canada possessed what can be characterized as "cereal box" French, digging for small plastic collectibles in boxes marked "GRATUIT." Packaged goods continue to make for convenient bilingual environmental print for both child and adult in Canada where federal regulations govern product labeling.

Plurilingualism is not so much the ability to translate into one or more languages nor does it reside solely in an individual's knowledge of two or more languages but more precisely, in the individual's capacity to consciously or unconsciously access this linguistic knowledge to achieve personal or interactive goals. To illustrate, we relate how as social actors, each of us has accessed our knowledge of languages in interactive ways as a forms of cultural, intellectual and social capital, to communicate and make meaning in two very different contexts.

\section{Sonya}

My childhood friend, Roya, was born and spent her early years in Afghanistan before immigrating with her family to Canada. At home, she speaks Farsi with her family members but when I (Sonya) visit her home, she and her family speak Hindi with me despite the fact that my home language is Punjabi and my ability to speak Hindi, acquired through numerous trips to India, limited by comparison. While Hindi is neither of our home languages, it proved to provide common linguistic ground when communicating with my friend and members of her family whose knowledge of Hindi derived almost entirely from their interest in watching Bollywood movies - a common form of entertainment in Afghanistan. By watching these movies without Farsi subtitles, her family acquired considerable aural comprehension and learned to express themselves in Hindi. Accessing our limited knowledge of a common language ultimately led to mutual respect for our identities, experiences, and culture.

\section{Karen}

In "Re-constructing Romania: An autobiographical account of foreign adoption: A Reader's Theatre in five voices," (Krasny, 2005), I (Karen) recount the story of our sons' adoption and how their journey from a small village in the Carpathian Mountains to our suburban home on the Canadian prairies is woven throughout the fabric of our family's heritage in the intersections of generations of Western and Eastern European voices. While shifting perspectives through voices past and present are employed in this performance ethnography to convey the complex and fragmentary construction of memory, the ethical and moral tensions of foreign adoption, and the media's impact on the construction of a global and social conscious, so too, are they reflective of the manner in which I actively enacted my proficiency in multiple languages and my experience of several cultures for the purposes of communication and to participate in intercultural interactions. I relied on my 
knowledge of Ukrainian words and simple phrases and cultural heritage to personally interact with people in our sons' Ukrainian village in Romania. Even more so, my ability to read and write in French allowed me to access meaning in legal documents written in Romanian. As Romance languages, both French and Romanian share the same Latin roots. This morphemic knowledge proved invaluable in providing me with some modicum of confidence as I negotiated a complex and ever changing legal landscape in a Communist country, politically and ideologically estranged from my own.

Increasingly, students come to school in possession of a range of linguistic and cultural resources. These illustrative examples are intended to demonstrate our lived appreciation for the ability to interactively access our various levels of proficiency in multiple languages to meet communicative and personal needs and by extension, to support our argument for a plurilingual orientation toward the expansion of students' linguistic repertoires. By recognizing the ways our students language differently across a range of contexts, we validate their cultural and linguistic identities and are in a better position help them make connections between and across languages and to leverage language as a resource in fostering academic success and social inclusion.

The Canadian educational context relies on specific terms to characterize students' linguistic backgrounds including mother tongue, first language, second language, heritage language, international/foreign language, official languages and standard languages. Often regarded as contentious, such terms are power laden and more often than not, fail to accurately capture how languages function in students' lives or their complex linguistic environments. Historically, language programs implemented in K to 12 and post-secondary institutions, and those developed for adult immigrants reflect these characterizations in both name and practice. Globalization, however, works to blur national boundaries of language and culture and as a consequence, makes possible culturally dynamic hybrids that obfuscate such definitions. Modern globalization has allowed for "a tremendous increase in the categories of migrants, not only in terms of nationality, ethnicity, language, and religion, but also in terms of motives, patterns and itineraries of migrations" (Blommaert \& Rampton, 2011, p. 1) to preclude the notion of ideal speaker-listeners. Piccardo (2013) further argues, "We are now increasingly aware that such a perfect individual does not exist, no more than a stable and perfectly known language exists" (p. 604).

\section{Canadian Classrooms as "Linguistic Graveyards"}

Although the Census data from Statistics Canada reveals that Canada is increasingly linguistically diversified, French and English continue to exercise hegemonic influence on parents' attitudes towards language use and instructional choices for their children. Given the longstanding status of English and French as Canada's official languages, these languages are invariably viewed as "languages of convergence and integration into Canadian society," and are seen as central to participation in Canadian life "as languages of work, education, and the provision of government services to the public" (Statistics Canada, 2012, p. 11). Cummins (2012) aptly captures the current situation stating, "Few would deny that Canada's cities are vibrant multilingual and multicultural environments; yet these same cities are linguistic graveyards for the home languages of countless children" (p. ix). For example, when children enter school in preschool or Junior Kindergarten they might be fluent in their home language(s), however, this fluency becomes challenged and at times, compromised by deliberate or involuntary messages 
conveyed through policy and practice. Undoubtedly, language maintenance is a worthy pedagogical aim in the multilingual classroom. We want to remind readers, however, that plurilingualism is not to be wholly equated with the ability to maintain one's home language, but to draw on multiple languages to "perceive and mediate the relationship which exist among languages and cultures" (Council of Europe, 2014, n.p.).

Li's (2006) case study of the first and second graders' biliteracy (Chinese/English reading and writing) and trilingual practices (Mandarin, Cantonese, and English) in three Chinese-Canadian homes found that while the parents in the study expected their children to become either biliterate or multilingual, factors such as their perceptions of their minority status in the host society and the availability of quality instruction in heritage language schools, language policies in the mainstream schools, and messages conveyed through the media prompted some to alter their home language practices to match those of the school with the aim of ensuring their child's success. As a consequence, Anthony's parents in Li's study wanted him to "learn real English" (p. 365) and not what they growingly observed as "Chinglish" prompting them to speak to their son exclusively in English at home. For Anthony's parents, Chinese-English hybridization was an unacceptable alternative to the standard English that they felt to be critical to their son's success. Conversely, and more closely related to the concept of plurilingualism, the parents of Alana saw the value of Chinese-language maintenance, as they believed that the skills learned for Chinese would help her achieve literacy skills in English. In response, Li argues, that helping immigrant children become bilingual or multilingual is a challenging task that requires concerted efforts between parents, public schools, and community organizations. We would further suggest, that parents and educators work toward an plurilingual understanding of children as social actors-interactively engaging their repertoires of language knowledge and skills in hybridized and interrelated ways so as to be able to communicate across a range of contexts as needed.

Conclusion: Plurilingualism as an Investment in Student Identity

Antonio Gramsci (1988) argues, "Each individual is the synthesis not only of existing relations but of the history of these relations. He $[$ sic $]$ is a précis of the past" (p. 326). Plurilingualism reflects the Gramacian idea that identity is constructed through our histories, but it is also constructed and negotiated through our social interactions of our everyday lives through language. Thorne and Lantolf (2007) describe a view of language that is:

...a historically contingent emergent system, one that provides a repertoire of semiotic devices that people can use to realize their communicative intentions, to interpret the communicative intentions of others and, perhaps most importantly, to foster the conditions of possibility for transforming self and community (p. 189).

This idea of "transforming self and community" has taken place as a result of globalization, where individuals have assumed a more fluid positioning of identity because of the expansive language practices that they are immersed in. In fact, Heller (2006) points out that linguistic minorities take advantage their "multiple linguistic and cultural resources in order to participate in a globalized economy" (p. 5). In regard to children, they too are 
immersed in language practices of "very different worlds-those of the family and those of the school" (Garcia 2009, p. 100) and it is within these communities that they construct their identities (Wenger, 1998; Lave \& Wegner, 1991). In response, we emphasize to educators that plurilingualism is not an instructional method but a critical means of performing identity.

As Pennycook (2007) argues, it is not so much that individuals use language based on their identity, but rather "we perform identity with words" (p. 73). All students, therefore, require opportunities to invest in their own linguistic practices. Norton and Toohey (2001) further argue "language choices available to children and their parents, as well as the discursive practices that are encouraged and supported in school, have an important impact on children's identity..."(p. 310). In this regard, it is increasingly important for educators to be conscious of the various connections between language and identity and how students perform identity through their languages (Garcia, 2009). While increased global migration and large concentrations of students in urban classrooms whose home language is not English have prompted much of the discussion on plurilingualism in Canada, we can envision the need for educator awareness as being more acute in mainstream classrooms with fewer linguistic minority students where issues of identity and power invariably intersect with issues of learning and instruction.

While we acknowledge the Council of Europe's original goals of promoting plurilingualism directed at developing global citizenry and no doubt, at enhancing economic or employment opportunities for the individual and the development of human capital, considering how languages are enacted and implemented in schools begins with a recognition of the social, political and historical influences that have been made manifest in a nation's existing policies on language and education. To this end, we have attempted to emphasize the aims of linguistic acceptance and the right of individuals to maintain and to continue to develop their plurilingualism against Canada's federal language policies by suggesting such aims 1) might serve to address the pressing need for socially and ethically responsive educational practice in linguistically diverse Canadian schools citing the GTA as one example and 2) might begin to redress, if only in small part, historical injustices committed against Canada's indigenous people in the form of cultural and linguistic annihilation.

We conclude by noting that any attempt to disrupt hegemonic linguistic and cultural structures is subject to the regional realities of uneven power structures. For example, we are reminded that there are still minority Francophone regions across Canada struggling to implement and maintain French language services and education. The implications for education are clear. Consistent with the ideals expressed in national language policies and frameworks, much of the professional learning opportunities for Canadian educators during the past four decades focused on the provision of English as a Second Language (ESL) and Français language seconde (FL2). Ongoing research and professional development into plurilingualism in schools will need to focus on how all students' experience of language expands, from the language of the home to that of the school and society at large, and to the languages of other people. We expect that language expansion and the degree to which students build communicative competences within which all knowledge of language contributes, interrelates and interacts will vary according the range of geographical, political, cultural, and social factors discussed and depend upon an educational commitment to students' right to exercise linguistic agency within a range of intercultural 
interactions.

\section{References}

Anderson, S., \& Jaafar B. S. (2006). Policy trends in Ontario education 1990-2006.

Toronto, Ontario: Ontario Institute for Studies in Education of the University of Toronto. Retrieved from: http://icec.oise.utoronto.ca/PDFfiles/FinalPolicyNarrative.pdf.pdf

Assembly of First Nations Principles for Revitalization of First Nations Languages (AFN). (1990). Towards Linguistic Justice for First Nations. Ottawa.

Krasny, K. (2005). Reconstructing Romania: An autobiographical account of foreign adoption. A readers' theatre in five voices. Journal of the Association for Research in Mothering, 7 (2), 154-167.

Krasny, K. (2009). Reading subjectivities in post-Soviet Ukraine: The contribution of diasporic narratives to an emerging independent national identity. Conference presentation from the Philosophy of Education Society of Australasia, Honolulu, Hawaii.

Blommaert, J. \& Rampton, B. (2011). Language and superdiversity. Diversities, 13(2), $1-22$.

Bourdieu, P., \& Passeron, J. C. (1977). Reproduction in education, society and culture ( $2^{\text {nd }}$ ed.) London; Beverly Hills: Sage Publications.

Brown, L. (2015, 18 November). Schools key to helping Syrian refugee children settle in. Toronto Star. Retrieved from http://www.thestar.com/news/canada/2015/11/18/schools-key-to-helpingsyrian-refugee-children-settle-in.html

Canagarajah, S., \& Liynage, I. (2012). Lessons from pre-colonial multilingualism. In M. Martin-Jones, A. Blackledge, \& A. Creese (Eds.), The Routledge handbook of multilingualism (pp. 49-65). London, England: Routledge.

Chumak-Horbatsch, R._(2012). Linguistically appropriate practice: A guide for working with young immigrant children. Toronto, Ontario: University of Toronto Press.

Coste, D., Moore, D., \& Zarate, G. (2009). Plurilingual and pluricultural competence. (original French version 1997). Studies towards a Common European Framework of Reference for language learning and teaching. Strasbourg: Council of Europe. Retrieved from: http://www.coe.int/t/dg4/linguistic/Source/SourcePublications/CompetencePlurili ngue09web_en.pdf

Council of Europe. (2001). Common European Framework of Reference for Languages. Strasbourg, France: Council of Europe Publishing. Retrieved from http://www. coe.int/t/dg4/linguistic/cadre_en.asp

Council of Europe. (n.d.). Policies for Plurilingualism. Council of Europe, Education and Language, Language Policy (website). Retrieved from http://www.coe.int/t/dg4/linguistic/Division en.asp

Dagenais, D. (2013). Multilingualism in Canada: Policy and Education in Applied Linguistics Research Annual Review of Applied Linguistics, 33, 286-301.

[Editorial]. (2016, February 10). Pop-up classrooms for Syrian refugee children is a bright idea. Toronto Star. Retrieved from http://www.thestar.com/opinion/editorials/2016/02/10/pop-up-classrooms-for- 
syrian-refugee-children-is-a-bright-idea-editorial.html

European Commission. (2007). Final report: High level group on multilingualism.

Luxembourg: European Communities. Retrieved from

http://ec.europa.eu/education/policies/lang/doc/multireport_en.pdf

Fairclough, N. (2003). Analysing Discourse: Textual Analysis for Social Research. London: Routledge.

Garcia, O. (2009). Bilingual education in the 21st century: A global perspective.

Chichester, UK: Wiley-Blackwell.

Garcia, O. (2009a). Education, multilingualism and translanguaging in the $21^{\text {st }}$ century. In

T. Skutnabb-Kangas, Social justice through multilingual education (pp. 140158). Bristol, UK ; Buffalo, NY: Multilingual Matters.

Gramsci, A. (1988). Notes for an introduction and approach to the study of philosophy and the history of culture. In D. Forgacs (ed.), A Gramsci Reader, (p. 326). Lawrence \& Wishart: London.

Government of Canada-Immigration and Citizenship. (2016). Map of destination communities and service provider organizations. Retrieved from http://www.cic.gc.ca/english/refugees/welcome/map.asp

Government of Canada-Immigration and Citizenship. (2016). \#WelcomeRefugees. Retrieved from http://www.cic.gc.ca/english/refugees/welcome/

Haque, E. (2012). Multiculturalism within a bilingual framework: Language, race, and belonging in Canada. Toronto; Buffalo: University of Toronto Press.

Heller, M. (2006). Linguistic minorities and modernity: A sociolinguistic ethnography (2nd ed.). London; New York: Continuum.

Lave, J., \& Wenger, E. (1991). Situated learning: Legitimate peripheral participation. Cambridge [England]; New York: Cambridge University Press.

Laing, G. (2013). Royal Commission on Bilingualism and Biculturalism. In The Canadian Encyclopedia. Historica Canada. Retrieved from http://www.thecanadianencyclopedia.ca/en/article/royal-commission-onbilingualism-and-biculturalism/\#links

Li, G. (2006). Biliteracy and trilingual practices in the home context: Case studies of Chinese-Canadian children. Journal of Early Childhood Literacy, 6(355), 355-381.

Ozga, J. (2000). Policy research in educational settings: Contested terrain. Buckingham: Open University Press.

Pennycook, A. (2007). The myth of English as an international language. In S. Makoni, \& A. Pennycook, (Eds.), Disinventing and reconstituting languages (pp. 90115). Toronto, Ontario: Multilingual Matters LTD.

Piccardo, E. (2013). Plurilingualism and curriculum design: Toward a synergic vision. TESOL Quarterly, 47(3), 600-614.

Piccardo, E., Berchoud, M., Cignatta, T., Mentz, O., \& Pamula, M. (2011). Pathways through assessing, learning and teaching in the CEFR. Strasbourg, France: Council of Europe Publishing. Retrieved http://www.ecml.at/tabid/277/PublicationID/64/Default.aspx

Royal Commission on Aboriginal Peoples. (1996). Report of the Royal Commission on Aboriginal Peoples: Looking Forward, Looking Back (Vol. 1). Ottawa.

Ruiz, R. (1984). Orientations in language planning. NABE Journal, 8(2), 15-35.

Schecter, S. R., \& Cummins, J. (2003). Multilingual Education in Practice: Using 
Diversity as a Resource. Portsmouth, NH: Heinemann.

Shohamy, E. G. (2006). Language policy: Hidden agendas and new approaches. London; New York: Routledge.

Statistics Canada. 2012. Linguistic Characteristics of Canadians-Language, 2011 Census

of Population. (Catalogue number 98-314-X2011001). Retrieved March 4, 2014 from Statistics Canada: http://www12.statcan.gc.ca/censusrecensement/2011/as-sa/98-314-x/98-314-x2011001-eng.pdf

Thorne S. L. \& Lantolf J. P. (2007). A linguistics of communicative activity. In S. Makoni, \& A. Pennycook (Eds.), Disinventing and reconstituting languages (pp. 170-195). Toronto, Ontario: Multilingual Matters LTD.

Toronto District School Board. (2014). Toronto District School Board Quick Facts. Retrieved from Toronto District School Board website: http://www.tdsb.on.ca/AboutUs/QuickFacts.aspx

University of Ottawa. (2016). "Site for language management in Canada (SLMC)." Official Languages and Bilingualism Institute (OLBI). Retrieved from University of Ottawa website: https://slmc.uottawa.ca/?q=native_peoples_languages

Vertovec, S. (2007). Super-diversity and its implications. Ethics and Racial Studies, 29(6), 1024-1054.

Wenger, E. (1999). Communities of practice: Learning, meaning, and identity. Cambridge: Cambridge University Press.

Author Biographies

Karen A. Krasny, $\mathrm{PhD}$ is Associate Professor of Language and Literacy at York University where she teaches undergraduate courses related to the teaching of Intermediate and Senior English and language arts and graduate seminars in theoretical models of reading and children's and adolescent literature. As a former teacher of FL2, she has longstanding interest in how Canadian language and multicultural policy has shaped educational practice.

Sonya Sachar, M.Ed, $\mathrm{PhD}$ (Candidate) is completing her doctoral studies in the Graduate Program in Education at York University. Her dissertation focuses on linguistic diversity in Toronto schools and builds upon her M. Ed. thesis, The Cognitive, Social, and Affective Dilemmas of Generation 1.5 English Language Learners: 1990-2011 which was the GPE's nomination for York University's Faculty of Graduate Studies Outstanding Thesis Award in 2011. 